\title{
Cropping Patterns in Mymensingh Region: Diversity, Constraint and Potential
}

\author{
A Khatun ${ }^{1 *}$, N Parvin 1 , M M R Dewan ${ }^{2}$ and A Saha ${ }^{1}$
}

\begin{abstract}
A consistent and comprehensive database on cropping pattern, cropping intensity and crop diversity of a particular area is the prime importance for guiding policy makers, researchers, extentionists and development agencies for the future research and development planning. The study was carried out all the upazilas of Mymensingh region during 2015-16 using pre-designed and pre-tested semistructured questionnaire with a view to document the existing cropping pattern, crop diversity and cropping intensity. The most dominant cropping pattern Boro-Fallow-T. Aman occupied about onehalf of net cropped area (NCA) of the region distributed to 46 out of 47 upazilas. Single Boro cropping pattern ranked the second position which covered $23 \%$ of NCA distributed in 45 upazilas. A total of 129 cropping patterns were identified in the whole area of Mymensingh region under this investigation. The highest number of (30) cropping patterns were identified in Pakundia upazila of Kishoreganj and the lowest was (10) in Sreebardi of Sherpur. The lowest crop diversity index (CDI) was reported (0.111) in Mithamoin of Kishoreganj followed by 0.114 at Khaliajuri in Netrokona. The highest value of CDI was observed 0.933 at Dewanganj in Jamalpur followed by 0.920 at Bhairab in Kishoreganj. The range of cropping intensity values was recorded $101-249 \%$. The maximum value was for Hossainpur and minimum for Itna and Mithamoin in Kishoreganj. At a glance the calculated CDI of Mymensingh region was 0.840 and the average cropping intensity was $187 \%$.
\end{abstract}

Key words: Cropping patterns, diversity index, cropping intensity, Madhupur tract and Sylhet Basin

\section{INTRODUCTION}

In Bangladesh total cultivable land is 8.5 million hectare and it is shrinking day by day. The annual loss of agricultural land is about $0.73 \%$ per annum due to construction of houses, roads and industrial infrastructure (BBS, 2014). There is no other alternative but need to increase total productivity per unit area of the prevailing lands. To increase system productivity it needs to bring diversity in enterprises for better utilization of limited resources. The production of the cropping patterns could be increased by changing cultivars and improving cultural management practices. There is some scope of increasing cropping intensity from existing level by improving the existing cropping patterns by incorporating short duration crops viz mustard, potato, mungbean and aus rice in the rice based cropping system.
Sustainable crop production in Bangladesh through improvement of cropping intensity in rice based cropping system is regarded as increasingly important in national issues such as food security, poverty alleviation and creation of job opportunity. The main challenge of the new millennium is to increase $50 \%$ yield per unit land area through manipulating the limited land resource. In order to produce more food within a limited area, the most important options are to increase the cropping intensity producing three or more crops over the same piece of land in a year and to increase the production efficiency of the individual crop by using optimum management practices (Mondal et al., 2015).

Actually, rice based monoculture exists in agriculture of the country. Rice monoculture gives us self-sufficiency in food production to some extent but it creates many problems.

${ }^{1}$ Rice Farming Systems Division, BRRI, Gazipur; ${ }^{2}$ BRRI RS Kushtia; *Corresponding author's E-mail: aminabrri@gmail.com 
Only rice based cropping pattern has been facing a number of problems like reduction of soil fertility, pests and diseases outbreaks in the crop fields, decline in water table, reduced production of non-rice crops, erodes biodiversity, creates nutritional imbalance (Hussain et al., 2001; Rahman, 2010). Crop diversification is considered as a strategy of reducing the reported problems. It is also considered as an effective approach to utilize scarce land and valuable water resources, which makes agriculture sustainable and environment friendly (Kumari et al., 2010).

Due to non-availability of information on cropping systems, researchers, development agencies and policy makers cannot rightly identify research areas. Depending on physiographic, soil, hydrological and climatic characteristics, thirty agro ecological zones (AEZ) have been identified in Bangladesh. Mymensingh region is one of the most distinctive regions in Bangladesh and it represents the agriculture and climatic situation of five districts i.e. Mymensingh, Netrokona, Kishoreganj, Jamalpur and Sherpur. In the context of physiography it belongs to seven different agroecological zones viz Young Brahmaputra and Jamuna Floodplain (AEZ8), Old Brahmaputra Floodplain (AEZ-9), Middle Meghna River Floodplain (AEZ-16), Old Meghna Estuarine Floodplain (AEZ-19), Sylhet Basin (AEZ-21), Northern and Western Piedmont Plains (AEZ-22) and Madhupur Tract (AEZ-28). Lion-share of the region frequently faces the occurrence of early flood, seasonal flood, late flood and also flash flood. In the basin area predominance of heavy clays and slow drainage and the dominance of noxious weeds are the critical parameters. Low moisture holding capacity, complex relief and soil pattern, erodibility of sloping soils and upland edges are main limitations for agricultural practices. Poor road communications in interior areas specially in the rainy season are big problems that mainly affect the marketing of produces.
Cropping pattern is defined as the yearly sequence, temporal and spatial arrangement of crops in a given land area. The Cropping pattern of a region reflects the geoclimatic, sociocultural, economic, historical and political conditions of a region (Agrawal and Kassam, 1976). The Cropping pattern and the changes therein depend on a large number of factors like climate, soil type, rainfall, agricultural technology, availability of irrigation facilities and other inputs, marketing and transport facilities and growth of agro-industries (Shahidullah et al., 2006; Neena, 1998; Gadge, 2003). According to Hossain (1996), the cropping pattern and the potential productivity of the crops of Bangladesh are determined by four climatic factors which are rainfall, evaporation, temperature and hours of light. Cropping patterns which depend not only on agro-ecological conditions but also on the spread of agricultural technologies especially irrigation technology. Total crop production has been changing due to changes in area under cultivation, yield rates, cropping pattern and prices of different crops. Shifting cropping pattern indicates changes in the composition of crops as well as their relative contribution to the total output growths due to proportionate change in areas. Changes in cropping pattern are pursued by either having technological backup in production of crops or supported by relative price advantages of the outputs or being influenced by the both. It is important to understand the changing pattern of crops over a longer period of time and identify the factors that caused changes in areas of the crops for taking appropriate policy measures in boosting and sustaining crop sector growth (Alam and Abedin, 1996).

Information on crops, major cropping patterns, area coverage by each pattern, rice yield in the pattern, level of adoption of modern rice variety in pattern by season across different land types in relation to their system productivity is lacking in compiled form. Detailed information on land situation and cropping systems is a precondition for a successful development programme. Department of Agricultural Extension (DAE) 
maintained upazila-wise information on individual crops, land use patterns and other related data. It's very difficult to understand the real agricultural situation of a region from these data. Generation of information will help to develop resource and demand based program for sustainable improvement of agricultural production system. Therefore, the present study was designed with an attempt to attain the following objectives to:

- Visualize the existing land use pattern at upazila and regional level

- Understand the existing scenario of cropping patterns in Mymensingh region

- Find out the crop diversity and cropping intensity at local and regional level.

\section{METHODOLOGY}

Forty-seven upazilas of Mymensingh, Kishoreganj, Netrokona, Jamalpur and Sherpur districts under Mymensingh agricultural region were the locations of this study. Data were collected using double stage procedure. At initial stage, data were collected through pre-tested semi-structured questionnaire from 47 pre-assigned Sub-Assistant Agriculture Officers (SAAO) of each upazila during August 2015 at upazila level. SAAOs were pre-selected by Agriculture Extension Officers (AEO), Additional Agriculture Officer (AAO) and Upazila Agriculture Officer (UAO) or altogether. Prior to data collection, the pre-tested questionnaire was explained along with proper guidelines to the AEOs or UAOs or both and handed over to them at each Deputy Director's office of Directorate of Agricultural Extension (DAE) during monthly meeting. The filled questionnaires were collected by the scientists of RFS Division, checked and analyzed to find the inconsistencies of the supplied data before validation workshop. All the inconsistencies among the information were documented. The collected data along with documented inconsistencies were discussed in district level workshop for necessary correction and validation. Second stage of data collection was daylong data validation workshop at district level. The workshop dates were 14 October for Jamalpur; 19 October for Kishoreganj; 17 November for Sherpur; 28 December 2015 for Netrokona and 5 January 2016 for Mymensingh. Four field-workers i.e. one SAPPO and three SAAOs experienced and engaged in cropbased data documentation, all officers from all upazilas viz UAOs, AEOs, AAEOs, DD (DAE), DD (Horticulture), DD of Seed Certification Agency, DTO and ADDs, one representative from Agricultural Training Institute (ATI) participated in the data validation workshop. The number of participants of validation workshop ranged from 55 to 96 in each district. All the participants were divided into three to four groups for data validation. Each group was facilitated by two RFSD scientists to finalize and validate the data and authenticated data were captured. Crop diversity index was calculated by using the following equation described by Kshirsagar et al. (1997).

$$
C D I_{i}=1-\sum_{j=o}^{n}\left(\frac{a_{i j}}{A_{i}}\right)^{2}
$$

Where, $\mathrm{CDI}_{\mathrm{i}}=$ Crop Diversity Index

$a_{i j}=$ Area planted to the $j^{\text {th }}$ crop in the $i^{\text {th }}$ location

$A_{i}=$ Total area planted under all crops

The index is zero for a land area growing only one crop. It approaches unity as the level of diversity increases. Compilation and processing of collected data were done using Micro Soft Excel programme. Descriptive statistics were used to facilitate the presentation of the findings.

\section{RESULTS AND DISCUSSION}

\section{Land use}

The agricultural land utilization scenario of Mymensingh region is presented in Table 1. The net cropped area (NCA) of this region is 950,580 ha. Crops occupied the particular land for round the year were considered under annual crops. The major annual crops reported in the region were pineapple, sugarcane, banana, 
Table 1. Land use of different upazilas in Mymensingh region (area in hectare), 2014-15.

\begin{tabular}{|c|c|c|c|c|c|c|c|c|c|c|}
\hline & Upazila & $\begin{array}{l}\text { Area of } \\
\text { upazila }\end{array}$ & $\begin{array}{l}\text { Annual } \\
\text { crop }\end{array}$ & SCA & DCA & TCA & QCA & Other & NCA & C.I. (\%) \\
\hline 01 & Baksiganj & 20438 & 190 & 750 & 8210 & 6240 & 70 & 130 & 15590 & 235 \\
\hline 02 & Dewanganj & 26618 & 1350 & 0 & 11490 & 5400 & 0 & 110 & 18350 & 222 \\
\hline 03 & Islampur & 35367 & 300 & 550 & 21900 & 2900 & 0 & 150 & 25800 & 208 \\
\hline 04 & Jamalpur sadar & 48924 & 590 & 1310 & 30280 & 5960 & 0 & 150 & 38290 & 211 \\
\hline 05 & Madarganj & 22548 & 40 & 1940 & 7500 & 10190 & 0 & 170 & 19840 & 242 \\
\hline 06 & Melandaha & 25843 & 320 & 830 & 14280 & 5780 & 20 & 190 & 21420 & 222 \\
\hline 07 & Sarishabari & 27313 & 20 & 2570 & 12680 & 6130 & 0 & 120 & 21520 & 217 \\
\hline 08 & Astogram & 35553 & 10 & 24490 & 920 & 290 & 0 & 100 & 25810 & 106 \\
\hline 09 & Bajitpur & 19300 & 360 & 5460 & 7290 & 1460 & 0 & 140 & 14710 & 170 \\
\hline 10 & Bhairab & 12167 & 10 & 2000 & 3660 & 1240 & 0 & 150 & 7060 & 189 \\
\hline 11 & Hossainpur & 11920 & 140 & 570 & 3190 & 4960 & 50 & 130 & 9040 & 249 \\
\hline 12 & Itna & 38100 & 0 & 30450 & 290 & 20 & 0 & 140 & 30900 & 101 \\
\hline 13 & Karimganj & 20052 & 310 & 2800 & 6810 & 4390 & 0 & 100 & 14410 & 209 \\
\hline 14 & Kishoreganj sadar & 19372 & 20 & 830 & 7965 & 4420 & 0 & 185 & 13420 & 227 \\
\hline 15 & Katiadi & 21912 & 370 & 2160 & 10160 & 2780 & 300 & 100 & 15870 & 205 \\
\hline 16 & Kuliarchar & 10401 & 110 & 2040 & 5430 & 1630 & 0 & 100 & 9310 & 194 \\
\hline 17 & Mithamoin & 21799 & 0 & 16650 & 130 & 20 & 0 & 100 & 16900 & 101 \\
\hline 18 & Nikli & 21400 & 10 & 15520 & 1550 & 0 & 0 & 130 & 17210 & 109 \\
\hline 19 & Pakundia & 18052 & 120 & 700 & 6580 & 4565 & 0 & 155 & 12120 & 231 \\
\hline 20 & Tarail & 15800 & 30 & 8280 & 4060 & 560 & 0 & 150 & 13080 & 140 \\
\hline 21 & Bhaluka & 44405 & 1500 & 2760 & 16570 & 1590 & 0 & 180 & 22600 & 188 \\
\hline 22 & Dhubaura & 25187 & 50 & 2950 & 11625 & 930 & 0 & 145 & 15700 & 187 \\
\hline 23 & Phulbaria & 39888 & 2200 & 3590 & 16050 & 4720 & 100 & 140 & 26800 & 197 \\
\hline 24 & Phulpur & 31500 & 40 & 470 & 20895 & 2575 & 0 & 160 & 24140 & 209 \\
\hline 25 & Gafargaon & 40116 & 210 & 5800 & 19040 & 3700 & 0 & 160 & 28910 & 192 \\
\hline 26 & Gouripur & 27676 & 40 & 2820 & 18820 & 800 & 0 & 160 & 22640 & 191 \\
\hline 27 & Haluaghat & 35607 & 90 & 8300 & 16020 & 2440 & 0 & 140 & 26990 & 178 \\
\hline 28 & Iswarganj & 28619 & 110 & 3600 & 17000 & 2600 & 0 & 150 & 23460 & 195 \\
\hline 29 & Muktagachha & 31290 & 1050 & 1200 & 18850 & 1630 & 0 & 120 & 22850 & 197 \\
\hline 30 & Mymensingh sadar & 38845 & 230 & 880 & 16880 & 7790 & 0 & 150 & 25930 & 226 \\
\hline 31 & Nandail & 32638 & 290 & 1300 & 19510 & 2580 & 0 & 110 & 23790 & 204 \\
\hline 32 & Trisal & 33601 & 250 & 1060 & 16960 & 7480 & 0 & 100 & 25850 & 224 \\
\hline 33 & Atpara & 19300 & 30 & 4020 & 9250 & 390 & 0 & 140 & 13830 & 173 \\
\hline 34 & Barhatta & 22200 & 20 & 1420 & 13280 & 980 & 0 & 120 & 15820 & 197 \\
\hline 35 & Durgapur & 27800 & 10 & 10340 & 7560 & 385 & 0 & 115 & 18410 & 146 \\
\hline 36 & Kalmakanda & 37523 & 40 & 22450 & 5430 & 400 & 0 & 120 & 28440 & 122 \\
\hline 37 & Kendua & 30527 & 80 & 4560 & 17500 & 1330 & 0 & 110 & 23580 & 186 \\
\hline 38 & Khaliajuri & 29746 & 10 & 18670 & 270 & 40 & 0 & 120 & 19110 & 102 \\
\hline 39 & Madan & 22587 & 10 & 9460 & 8330 & 350 & 0 & 160 & 18310 & 150 \\
\hline 40 & Mohanganj & 24800 & 30 & 8845 & 6835 & 210 & 0 & 160 & 16080 & 146 \\
\hline 41 & Netrokona sadar & 33297 & 50 & 3640 & 18090 & 950 & 0 & 120 & 22850 & 188 \\
\hline 42 & Purbadhala & 31442 & 30 & 2155 & 20000 & 970 & 0 & 125 & 23280 & 195 \\
\hline 43 & Jhenaigati & 20839 & 130 & 1260 & 13040 & 770 & 0 & 130 & 15330 & 196 \\
\hline 44 & Nakla & 17479 & 180 & 0 & 11610 & 2850 & 0 & 140 & 14780 & 218 \\
\hline 45 & Nalitabari & 32777 & 130 & 290 & 21190 & 2180 & 0 & 140 & 23930 & 207 \\
\hline 46 & Sherpur sadar & 35781 & 300 & 1530 & 17400 & 8710 & 0 & 160 & 28100 & 225 \\
\hline \multirow[t]{2}{*}{47} & Sreebardi & 25156 & 20 & 1250 & 13900 & 3100 & 0 & 150 & 18420 & 210 \\
\hline & Mymensingh region & & 11430 & 244520 & 556280 & 131385 & 540 & 6425 & 950580 & 187 \\
\hline
\end{tabular}


papaya, betel leaf, ginger and turmeric. The annual crops area in different upazilas ranged from zero to 2,200 ha and it accounted only $1.21 \%$ of the net cropped area in the region. At a glance the region possesses $26 \%$ single cropped area (SCA), 59\% double cropped area (DCA), $14 \%$ triple cropped area (TCA) and $0.06 \%$ quadruple cropped area. The SCA had the major share of NCA in Ashtagram, Itna, Mithamoin, Nikli and Tarail upazilas of Kishoreganj district; Durgapur, Kalmakanda, Khaliajuri, Madan and Mohanganj upazilas of Netrokona district followed by corresponding double cropped area (DCA). The rest of the upazilas were dominated by DCA (Table 1). Triple cropped area is exceptionally dominating in Madarganj upazila of Jamalpur district and Hossainpur upazila of Kishoreganj district. The quadruple cropped area was found only in Baksiganj and Melandaha upazila of Jamalpur district; Hossainpur and Katiadi upazila of Kishoreganj district and Phulbaria upazila of Mymensingh district. The area which could not be defined under SCA, DCA, TCA or QCA was considered as other whose coverage is less than $1 \%$ of the NCA.

\section{Cropping patterns of Mymensingh}

In total 129 cropping patterns were observed in Mymensingh region of which six cropping patterns with exclusive rice crop covers over $77 \%$ of the NCA. There were 40 cropping patterns with exclusive non-rice crop covering over $5 \%$ of the NCA. Rest of the NCA i.e. about $18 \%$ area is covered by 83 rice - non rice cropping patterns (Appendix 1).

\section{Exclusive rice cropping}

Crop-combination analysis is an important aspect of agricultural geography. It's practical in different ways. Firstly, it provides sufficient understanding of an individual crop. Secondly, it helps us in interpreting some aspects of social and economic environment of the region. It further indicates the problems and basis for agricultural planning. In Mymensingh region, rice is the most dominant crop and it accounts for the largest proportion of total cropped area (BBS, 2014). Exclusively rice- based cropping patterns occupied $77.40 \%$ land of the net cropped area (Table 2). The highest area coverage (49.61\%) was observed by BoroFallow-T. Aman cropping pattern and common in all upazilas except Mithamoin in Kishoreganj district. Single Boro cropping pattern is available in 45 upazilas covered $23.00 \%$ land area which is next to Boro-Fallow-T. Aman cropping pattern. A wide variation was observed in all other exclusive rice-based cropping patterns in respect of area and existing upazilas as well. Boro-Aus-T. Aman occupied 2.29\% land area exists in 22 upazilas followed by Fallow-Aus-T. Aman (1.27\%) and single T. Aman (1.18\%) in 9 upazilas (Table 2).

\section{Exclusive non-rice crops}

In the current investigation, 40 cropping patterns were identified that was free from rice. Among them first 30 have been arranged in descending order in Table 3 . The rest 10 patterns with negligible area coverage in Table 7 are arranged with other patterns of different categories. The agroclimatic conditions of Mymensingh region are suitable for growing rice year-round and rice takes up three-fourths of cropped areas. Though rice has a wide adaptation to different environmental situation, there are 40 exclusively non-rice cropping patterns occupying 49,935 ha land area which covers $5.25 \%$ of net cropped area in this region (Table 3 ). Among them the highest area $(0.89 \%)$ was occupied by VagetabVegetable-Vegetable cropping pattern existed in 23 out of 47 upazilas. Vegetables cultivated both in Rabi and Kharif-I seasons covered $0.48 \%$ of net cropped area found in 14 upazilas. The cropping patterns, Maize-Jute-Fallow (0.41\%), Vegetable-Fallow-Fallow (0.39\%) and WheatJute-Fallow $(0.30 \%)$ existed in six, nine and seven upazilas, respectively (Table 3 ). Nowa-days significant increase in the production of non-rice crops is ensuring biodiversity and nutritional balance through reducing the negative impacts of rice monoculture.

Aggregate of the 40 patterns have had $5.25 \%$ of NCA. In critical comparison it is clear that exclusive rice area is about 15 folds of 
Table 2. Cropping patterns with exclusive rice in Mymensingh region, 2014-15.

\begin{tabular}{llrrr}
\hline & Cropping pattern & Area (ha) & \% of NCA & Frequency (no. of upazila) \\
\hline 1 & Boro-Fallow- T. Aman & 471550 & 49.61 & 46 \\
2 & Boro-Fallow-Fallow & 218650 & 23.00 & 45 \\
3 & Boro-Aus- T. Aman & 21750 & 2.29 & 22 \\
4 & Fallow-Aus- T. Aman & 12110 & 1.27 & 9 \\
5 & Fallow-Fallow- T. Aman & 11180 & 1.18 & 9 \\
6 & Boro-Aus-Fallow & 500 & 0.05 & 3 \\
\hline & Total & 735740 & 77.40 & --- \\
\hline
\end{tabular}

Table 3. Cropping patterns with exclusive non-rice in Mymensingh region, 2014-15.

\begin{tabular}{|c|c|c|c|c|}
\hline & Cropping pattern & Area (ha) & $\%$ of NCA & Frequency (no. of upazila) \\
\hline 01 & Vegetable-Vegetable-Vegetable & 8500 & 0.89 & 23 \\
\hline 02 & Vegetable-Vegetable-Fallow & 4550 & 0.48 & 14 \\
\hline 03 & Maize-Jute-Fallow & 3890 & 0.41 & 6 \\
\hline 04 & Vegetable-Fallow-Fallow & 3630 & 0.38 & 9 \\
\hline 05 & Wheat-Jute-Fallow & 2820 & 0.30 & 7 \\
\hline 06 & Sweet potato-Fallow-Fallow & 2700 & 0.28 & 25 \\
\hline 07 & Chilli-Jute-Fallow & 2670 & 0.28 & 9 \\
\hline 08 & Fallow-Fallow-Blackgram & 2400 & 0.25 & 15 \\
\hline 09 & Vegetable-Jute-Fallow & 2170 & 0.23 & 8 \\
\hline 10 & Chilli-Fallow-Fallow & 2000 & 0.21 & 11 \\
\hline 11 & Groundnut-Fallow-Fallow & 1875 & 0.20 & 18 \\
\hline 12 & Onion-Jute-Fallow & 1720 & 0.18 & 5 \\
\hline 13 & Chilli-Vegetable-Fallow & 1225 & 0.13 & 15 \\
\hline 14 & Mustard-Jute-Fallow & 1210 & 0.13 & 4 \\
\hline 15 & Maize-Fallow-Fallow & 1160 & 0.12 & 8 \\
\hline 16 & Onion-Vegetable-Vegetable & 885 & 0.09 & 18 \\
\hline 17 & Potato-Jute-Fallow & 810 & 0.09 & 5 \\
\hline 18 & Grasspea-Jute-Fallow & 660 & 0.07 & 5 \\
\hline 19 & Garlic-Vegetable-Vegetable & 640 & 0.07 & 15 \\
\hline 20 & Mustard-Fallow-Fallow & 540 & 0.06 & 2 \\
\hline 21 & Blackgram-Jute-Fallow & 500 & 0.05 & 4 \\
\hline 22 & Garlic-Jute-Fallow & 480 & 0.05 & 4 \\
\hline 23 & Lentil-Jute-Fallow & 470 & 0.05 & 6 \\
\hline 24 & Wheat-Vegetable-Vegetable & 460 & 0.05 & 2 \\
\hline 25 & Potato-Chilli-Fallow & 330 & 0.03 & 3 \\
\hline 26 & Sweet potato-Jute-Fallow & 300 & 0.03 & 3 \\
\hline 27 & Wheat-Jute-Blackgram & 250 & 0.03 & 1 \\
\hline 28 & Coriander-Fallow-Fallow & 205 & 0.02 & 10 \\
\hline 29 & Vegetable-Fallow-Blackgram & 180 & 0.02 & 3 \\
\hline 30 & Coriander-Jute-Fallow & 170 & 0.02 & 2 \\
\hline \multirow[t]{2}{*}{$31-40$} & Other 10 patterns (in Table 7) & 535 & 0.06 & - \\
\hline & Total & 49935 & 5.25 & \\
\hline
\end{tabular}


exclusive non-rice area. The rapid increase in human population creates additional pressure on natural resources at above optimal levels of their inherent potential, which resulted the loss of biodiversity, serious soil erosion leading to depletion of plant nutrient, gradual degradation and decline in productivity and carrying capacity, etc. Even though appropriate cropping patterns may facilitate maximum possible land utilization as well as efficient use of other scarce resources in a sustainable manner. Diversified cropping pattern may be an option for the farmers as a coping strategy against risks (Mandal and Bezbaruah, 2013).

\section{Oil-seed crops}

Seventeen cropping patterns in combination of oil-seed crops occupy 41,810 ha land area which covers $4.40 \%$ of net cropped area (Table 4 ). Among the different oil crops, mustard takes up a great portion. The highest area coverage $(2.34 \%)$ was recorded by Mustard-Boro-T. Aman cropping pattern which existed in 29 out of 47 upazilas. The second one Mustard-BoroFallow cropping pattern covered $1.27 \%$ land area existed in 18 upazilas. Though all these patterns occupied a poor portion of net cropped area, this could be the beginning, and the full potential of diversification has yet to be fully achieved to increase emphasis on the expansion of oil-seed crops in the Rabi season.
Vegetable and spices crops

Sixty-five cropping patterns have been arranged in descending order according to area coverage in Table 5. Potato, sweet potato, vegetable of Rabi, Kharif-I and Kharif-II; spices viz chilli, onion, garlic and coriander are included in this list. A row is included at the end of the Table 5 representing an aggregate of 15 patterns of vegetable and spices which is elaborately presented in the Table 7 with other patterns of different categories. The most contributing cropping pattern is VegetableVegetable-T. Aman covering $0.94 \%$ of NCA which distributed over 13 upazilas.

Year-round vegetable was the second dominant cropping pattern which possessed 8,500 ha; however, it is most widely available in 23 upazilas. Vegetable-Fallow-T. Aman is the third dominant pattern distributed among 16 upazilas. For availability of irrigation water in dry season, supply of modern varieties of various crops, skilled technology transfer system, knowledge on modern crop management practices, high market value of fresh vegetable, good communication and marketing facilities are enhancing the extensive production of various types of vegetables in Mymensingh region (FAO, 1988). Now-a-days vegetable dominating cropping patterns are gradually increasing to meet up the demand of home and abroad. Vegetable like colocasia, okra, amaranthus, brinjal, cucurbits, etc are grown in medium upland adjacent to rice fields

Table 4. Area for oil-seed crops in Mymensingh region, 2014-15.

\begin{tabular}{llrcc}
\hline & Cropping pattern & Area (ha) & \% of NCA & Frequency (no. of upazila) \\
\hline 01 & Mustard-Boro- T. Aman & 22270 & 2.34 & 29 \\
02 & Mustard-Boro-Fallow & 12090 & 1.27 & 18 \\
03 & Groundnut-Fallow-Fallow & 1875 & 0.20 & 18 \\
04 & Mustard-Jute- T. Aman & 1840 & 0.19 & 7 \\
05 & Mustard-Jute-Fallow & 1210 & 0.13 & 4 \\
06 & Mustard-Aus- T. Aman & 580 & 0.06 & 4 \\
07 & Mustard-Fallow-Fallow & 540 & 0.06 & 2 \\
08 & Mustard-Boro-Aus- T. Aman & 420 & 0.04 & 3 \\
09 & Mustard-Fallow- T. Aman & 350 & 0.04 & 2 \\
10 & Groundnut-Jute- T. Aman & 330 & 0.03 & 7 \\
$11-17$ & Other seven patterns (in Table 7) & 305 & 0.02 & - \\
\hline
\end{tabular}


Table 5. Area for vegetable and spices crops in Mymensingh region, 2014-15.

\begin{tabular}{|c|c|c|c|c|}
\hline & Cropping pattern & Area (ha) & $\%$ of NCA & Frequency (no. of upazila) \\
\hline 01 & Vegetable-Vegetable- T. Aman & 8910 & 0.94 & 13 \\
\hline 02 & Vegetable-Vegetable-Vegetable & 8500 & 0.89 & 23 \\
\hline 03 & Vegetable-Fallow- T. Aman & 7460 & 0.78 & 16 \\
\hline 04 & Potato-Boro- T. Aman & 6080 & 0.64 & 16 \\
\hline 05 & Vegetable-Boro- T. Aman & 4730 & 0.50 & 13 \\
\hline 06 & Vegetable-Vegetable-Fallow & 4550 & 0.48 & 14 \\
\hline 07 & Potato-Jute- T. Aman & 4360 & 0.46 & 16 \\
\hline 08 & Vegetable-Fallow-Fallow & 3630 & 0.38 & 9 \\
\hline 09 & Chilli-Boro-Jute & 3600 & 0.38 & 3 \\
\hline 10 & Vegetable-Jute- T. Aman & 3520 & 0.37 & 13 \\
\hline 11 & Boro-Vegetable- T. Aman & 3420 & 0.36 & 3 \\
\hline 12 & Chilli-Aus-Fallow & 2935 & 0.31 & 6 \\
\hline 13 & Sweet potato-Fallow-Fallow & 2700 & 0.28 & 25 \\
\hline 14 & Chilli-Jute-Fallow & 2670 & 0.28 & 9 \\
\hline 15 & Vegetable-Jute-Fallow & 2170 & 0.23 & 8 \\
\hline 16 & Chilli-Fallow-Fallow & 2000 & 0.21 & 11 \\
\hline 17 & Chilli-Fallow- T. Aman & 1840 & 0.19 & 10 \\
\hline 18 & Potato-Boro-Fallow & 1770 & 0.19 & 8 \\
\hline 19 & Onion-Jute-Fallow & 1720 & 0.18 & 5 \\
\hline 20 & Vegetable-Aus-T. Aman & 1350 & 0.14 & 7 \\
\hline 21 & Chilli-Vegetable-Fallow & 1225 & 0.13 & 15 \\
\hline 22 & Potato-Aus- T. Aman & 1210 & 0.13 & 8 \\
\hline 23 & Chilli-Jute- T. Aman & 1150 & 0.12 & 4 \\
\hline 24 & Potato-Vegetable- T. Aman & 1090 & 0.11 & 8 \\
\hline 25 & Potato-Fallow- T. Aman & 1000 & 0.11 & 10 \\
\hline 26 & Fallow-Vegetable- T. Aman & 980 & 0.10 & 2 \\
\hline 27 & Onion-Jute- T. Aman & 940 & 0.10 & 11 \\
\hline 28 & Boro-Vegetable (Float/Norm) & 900 & 0.09 & 5 \\
\hline 29 & Vegetable-Aus-Fallow & 900 & 0.09 & 2 \\
\hline 30 & Onion-Vegetable-Vegetable & 885 & 0.09 & 18 \\
\hline 31 & Potato-Jute-Fallow & 810 & 0.09 & 5 \\
\hline 32 & Onion-Fallow- T. Aman & 805 & 0.08 & 9 \\
\hline 33 & Vegetable-Boro-Fallow & 690 & 0.07 & 2 \\
\hline 34 & Garlic-Vegetable-Vegetable & 640 & 0.07 & 15 \\
\hline 35 & Garlic-Fallow- T. Aman & 610 & 0.06 & 5 \\
\hline 36 & Chilli-Vegetable- T. Aman & 515 & 0.05 & 5 \\
\hline 37 & Vegetable-Boro-Jute & 500 & 0.05 & 1 \\
\hline 38 & Garlic-Jute-Fallow & 480 & 0.05 & 4 \\
\hline 39 & Wheat-Vegetable-Vegetable & 460 & 0.05 & 2 \\
\hline 40 & Potato-Aus-Fallow & 400 & 0.04 & 1 \\
\hline 41 & Garlic-Jute- T. Aman & 340 & 0.04 & 8 \\
\hline 42 & Potato-Boro-Jute & 340 & 0.04 & 1 \\
\hline 43 & Potato-Chilli-Fallow & 330 & 0.03 & 3 \\
\hline 44 & Sweet potato-Fallow- T. Aman & 310 & 0.03 & 6 \\
\hline 45 & Sweet potato-Jute-Fallow & 300 & 0.03 & 3 \\
\hline 46 & Chilli-Aus- T. Aman & 250 & 0.03 & 1 \\
\hline 47 & Coriander-Fallow-Fallow & 205 & 0.02 & 10 \\
\hline 48 & Vegetable-Fallow-Blackgram & 180 & 0.02 & 3 \\
\hline 49 & Coriander-Fallow- T. Aman & 170 & 0.02 & 5 \\
\hline 50 & Coriander-Jute-Fallow & 170 & 0.02 & 2 \\
\hline \multirow[t]{2}{*}{$51-65$} & Other 15 patterns (in Table 7) & 535 & 0.06 & - \\
\hline & Total vegetable and spices crops & 97235 & 10.23 & \\
\hline
\end{tabular}


during rainy season and potato, sweet gourd, cole crops, leafy vegetable etc are grown during winter season in Tripura (Das et al., 2015).

\section{Fibre crops}

Forty cropping patterns of jute crops occupy 72,230 ha land area which covers $7.60 \%$ land of net cropped area. The highest area coverage $(1.91 \%)$ was occupied by Boro-Jute-T. Aman which existed in 15 upazilas out of 47 (Table 6). The second one Wheat-Jute-T. Aman cropping pattern covered $0.75 \%$ land area, however, existed in 27 upazilas. Fallow-Jute-T. Aman, Potato-Jute-T. Aman and Maize-Jute-Fallow were found in 12, 16 and 6 upzilas covered 0.58 , 0.46 and $0.41 \%$ of net cropped area, respectively.
Well-drained light-textured soil makes the friendly situation for early growth stages of jute. High temperature, high humidity, satisfactory rainfall is the pre-requisites for cultivation of the crop which are available in Mymensingh region. Clear sun-shine during the harvesting period is an extra facility for post-harvest management of fibre and stick. Generally sufficient water for jute retting is not available in the whole region, however, it is sporadically available. Now-adays jute-stick also has a good market value with export potential. If modern technology for fibre separation could be made available the farmers will be encouraged for extensive jute cultivation in the region (FAO, 1988).

Table 6. Area for jute production in Mymensingh region, 2014-15.

\begin{tabular}{|c|c|c|c|c|}
\hline & Cropping pattern & Area (ha) & $\%$ of NCA & Frequency (no. of upazila) \\
\hline 01 & Boro-Jute- T. Aman & 18150 & 1.91 & 15 \\
\hline 02 & Wheat-Jute- T. Aman & 7150 & 0.75 & 27 \\
\hline 03 & Fallow-Jute- T. Aman & 5540 & 0.58 & 12 \\
\hline 04 & Potato-Jute- T. Aman & 4360 & 0.46 & 16 \\
\hline 05 & Maize-Jute-Fallow & 3890 & 0.41 & 6 \\
\hline 06 & Chilli-Boro-Jute & 3600 & 0.38 & 3 \\
\hline 07 & Vegetable-Jute- T. Aman & 3520 & 0.37 & 13 \\
\hline 08 & Wheat-Jute-Fallow & 2820 & 0.30 & 7 \\
\hline 09 & Chilli-Jute-Fallow & 2670 & 0.28 & 9 \\
\hline 10 & Boro-Jute-Fallow & 2330 & 0.25 & 5 \\
\hline 11 & Maize-Jute- T. Aman & 2220 & 0.23 & 4 \\
\hline 12 & Vegetable-Jute-Fallow & 2170 & 0.23 & 8 \\
\hline 13 & Mustard-Jute- T. Aman & 1840 & 0.19 & 7 \\
\hline 14 & Onion-Jute-Fallow & 1720 & 0.18 & 5 \\
\hline 15 & Mustard-Jute-Fallow & 1210 & 0.13 & 4 \\
\hline 16 & Chilli-Jute- T. Aman & 1150 & 0.12 & 4 \\
\hline 17 & Onion-Jute- T. Aman & 940 & 0.10 & 11 \\
\hline 18 & Potato-Jute-Fallow & 810 & 0.09 & 5 \\
\hline 19 & Lentil-Jute- T. Aman & 745 & 0.08 & 9 \\
\hline 20 & Blackgram-Jute- T. Aman & 670 & 0.07 & 6 \\
\hline 21 & Grasspea-Jute-Fallow & 660 & 0.07 & 5 \\
\hline 22 & Blackgram-Jute-Fallow & 500 & 0.05 & 4 \\
\hline 23 & Vegetable-Boro-Jute & 500 & 0.05 & 1 \\
\hline 24 & Garlic-Jute-Fallow & 480 & 0.05 & 4 \\
\hline 25 & Lentil-Jute-Fallow & 470 & 0.05 & 6 \\
\hline 26 & Garlic-Jute- T. Aman & 340 & 0.04 & 8 \\
\hline 27 & Potato-Boro-Jute & 340 & 0.04 & 1 \\
\hline 28 & Groundnut-Jute- T. Aman & 330 & 0.03 & 7 \\
\hline 29 & Sweet potato-Jute-Fallow & 300 & 0.03 & 3 \\
\hline 30 & Wheat-Jute-Blackgram & 250 & 0.03 & 1 \\
\hline 31 & Coriander-Jute-Fallow & 170 & 0.02 & 2 \\
\hline \multirow[t]{2}{*}{$32-40$} & Other nine patterns (in Table 7) & 385 & 0.04 & - \\
\hline & Total area for jute & 72230 & 7.60 & \\
\hline
\end{tabular}




\section{Sporadic and distinct cropping patterns}

There were some cropping patterns which were extremely location-specific covering a large area. The Maize-Jute-Fallow is grown in 2,000 ha and 350 ha in Dewanganj and Islampur upazilas, respectively under Jamalpur district. Chilli-Boro-Jute is cultivated in 2,650 ha in Madarganj of Jamalpur and 500 ha in Bhairab of Kishoreganj district. Boro-Vegetable- T. Aman is limited to two upazilas viz Trisal (1,600 ha) and sadar upazila (1,700 ha) of Mymensingh district.

\section{Rare cropping patterns}

Forty cropping patterns with minor area coverage and narrow existence occupy 1,845 ha land area which covers $0.19 \%$ of net cropped area of this region. The area coverage of these patterns ranged from trace to $0.02 \%$ of net cropped area each existed in one to four upazilas. Among these patterns, three were single cropped, 16 were double cropped and 21 were triple cropped cropping patterns covering negligible area (Table 7).

\section{Most dominant cropping pattern}

In Mymensingh region, the most dominant cropping pattern was Boro-Fallow- T. Aman covering $49.6 \%$ of NCA and was available in 46 upazilas out of 47 (Table 8). The highest area under this cropping pattern was recorded 25,200 ha in Jamalpur sadar upazila which represents $5.34 \%$ of the total Boro-Fallow- T. Aman area of the region. Purbadhala upazila of Netrokona district has owned the highest area in consideration of indivdual upazila and occupied $86 \%$ of its NCA for this pattern alone. The least area coverage was reported in Khaliajuri, Nikli and Itna upazila. In the countrywide compilation of data it was observed that Boro-Fallow-T. Aman was the most dominant cropping pattern in Bangladesh covering 2.31 million ha (27\% of NCA in the country) with its distribution in 426 upazilas of 63 districts (Nasim et al., 2017).

\section{Second dominant cropping pattern}

Boro-Fallow-Fallow cropping pattern ranked the second position in Mymensingh region occupying $23.0 \%$ of NCA distributed in 45 upazilas (Table 9). However, their magnitude of contribution to the region was different, ranging 0.26 (Jamalpur sadar) to $95.24 \%$ (Khaliajuri) of the NCA. The major share of this pattern was from Itna, Astogram, Khaliajuri, Kalmakanda, Mithamoin, Nikli and Durgapur upazilas. Itna upazila of Kishoreganj district hold the higest area $(27,500 \mathrm{ha})$ under this single Boro cropping pattern. Itna and Astogram upazilas together contributed remarkable share (23.19\%) of single Boro cropping area in the region. This pattern was frequent and concurrently experienced by early flash flood in April and cold injury at reproductive stage. Diversified cropping pattern may be an option for the farmer as a coping strategy in flood prone areas (Mandal and Bezbaruah, 2013), but scope of diversification is limited due to environmental and climatic condition (FAO, 1988). In the country-wide compilation of data it was observed that the single Boro was the second dominant cropping pattern in Bangladesh covering 1.14 million ha $(13 \%$ of NCA in the country) with its distribution in 342 upazilas of 59 districts (Nasim et al., 2017).

\section{Third dominant cropping pattern}

Mustard-Boro-T. Aman cropping pattern grips the third largest area coverage 22,270 ha distributed in 29 out of 47 upazilas in Mymensinghregion. This area was an equivalent to $2.34 \%$ of NCA in the region. Jamalpur sadar has an area of 3,300 ha which stands for $14.82 \%$ of the total area under this pattern in the region (Table 10). Sarishabari ranks in second position for this pattern; however, this upazila has allotted the largest share $(13.01 \%)$ of its NCA. In the country-wide compilation of data it was observed that Mustard-Boro- T. Aman was the $6^{\text {th }}$ dominant cropping pattern in Bangladesh covering 1.85 lac ha $(2.16 \%$ of NCA in the country) with its distribution in 203 upazilas of 51 districts (Nasim et al., 2017).

\section{Fourth dominant cropping pattern}

Boro-Aus-T. Aman cropping pattern was recorded as the fourth dominant cropping pattern occupied 21,750 ha distributed to 22 out of 47 
Table 7. Rare cropping patterns covering non-significant area in Mymensingh region, 2014-15.

\begin{tabular}{|c|c|c|c|c|c|}
\hline & Cropping pattern & Area (ha) & $\%$ of NCA & Freq. & Upazila \\
\hline 01 & Maize-Aus- T. Aman & 150 & 0.02 & 3 & Katiadi+Pakundia+Gafargaon \\
\hline 02 & Garlic-Fallow-Fallow & 110 & 0.01 & 4 & Nikli+Itna+Mithamoin+Durgapur \\
\hline 03 & Grasspea-Aus- T. Aman & 110 & 0.01 & 3 & Kishoreganj+Gafargaon+Nandail \\
\hline 04 & Wheat-Fallow-Fallow & 110 & 0.01 & 2 & Astogram+Mithamoin \\
\hline 05 & Mungbean-Jute-Fallow & 100 & 1.91 & 2 & Katiadi+Pakundia \\
\hline 06 & Wheat-Aus-Blackgram & 100 & 0.75 & 1 & Madarganj \\
\hline 07 & Groundnut-Sesame-Fallow & 90 & 0.58 & 2 & Bhairab+Pakundia \\
\hline 08 & Pea-Aus-Vegetable & 90 & 0.46 & 1 & Gafargaon \\
\hline 09 & Potato-Boro-Jute- T. Aman & 70 & 0.41 & 2 & Baksiganj+Melandaha \\
\hline 10 & Sesame-Fallow- T. Aman & 55 & 0.38 & 3 & Jamalpur sadar +Tarail+Dhubaura \\
\hline 11 & Grasspea-Boro-Fallow & 50 & 0.37 & 1 & Dewanganj \\
\hline 12 & Maize-Vegetable- T. Aman & 50 & 0.30 & 1 & Nakla \\
\hline 13 & Mungbean-Fallow- T.Aman & 50 & 0.28 & 2 & Jamalpur sadar +Tarail \\
\hline 14 & Mungbean-Jute- T. Aman & 50 & 0.25 & 3 & Baksiganj+Phulpur+Mym. sadar \\
\hline 15 & Sweet Potato-Jute- T. Aman & 50 & 0.23 & 1 & Muktagachha \\
\hline 16 & W.Melon-Aus- T. Aman & 50 & 0.23 & 1 & Kalmakanda \\
\hline 17 & Boro-Sesbania- T. Aman & 40 & 0.19 & 1 & Madarganj \\
\hline 18 & Grasspea-Fallow- T. Aman & 40 & 0.18 & 1 & Jamalpur sadar \\
\hline 19 & Grasspea-Jute- T. Aman & 40 & 0.13 & 3 & Baksiganj+Karimganj+Mym. sadar \\
\hline 20 & Groundnut- Aus- T. Aman & 40 & 0.12 & 1 & Kuliarchar \\
\hline 21 & Sesame-Aus-Fallow & 40 & 0.10 & 1 & Islampur \\
\hline 22 & Lentil-Fallow- T. Aman & 35 & 0.09 & 4 & Bhairab+Bhaluka+Dhubaura+Durgapur \\
\hline 23 & Maize-Mungbean-Vegetable & 30 & 0.08 & 1 & Pakundia \\
\hline 24 & Millet(cheena)-F-F & 30 & 0.07 & 1 & Melandaha \\
\hline 25 & Millet(Kaon)+Sesame-F & 30 & 0.07 & 1 & Madarganj \\
\hline 26 & Potato-Boro-Aus- T. Aman & 30 & 0.05 & 1 & Hossainpur \\
\hline 27 & Sesame-Jute- T. Aman & 30 & 0.05 & 1 & Baksiganj \\
\hline 28 & Must-Boro-Jute- T. Aman & 20 & 0.05 & 1 & Baksiganj \\
\hline 29 & Onion-Aus- T. Aman & 20 & 0.05 & 1 & Hossainpur \\
\hline 30 & Onion-Maize- T. Aman & 20 & 0.04 & 1 & Pakundia \\
\hline 31 & Chickpea-Fallow-T. Aman & 15 & 0.04 & 2 & Dhubaura+Phulbaria \\
\hline 32 & Coriander-Jute- T. Aman & 15 & 0.03 & 2 & Melandaha+Phulpur \\
\hline 33 & Coriander-Vegetable-Fallow & 15 & 0.03 & 2 & Tarail+Phulpur \\
\hline 34 & Pea-Fallow- T. Aman & 15 & 0.03 & 2 & Dhubaura+Mym. sadar \\
\hline 35 & Chickpea-Jute-T. Aman & 10 & 0.02 & 1 & Mymensingh sadar \\
\hline 36 & Garlic-Aus-Fallow & 10 & 0.01 & 1 & Bhaluka \\
\hline 37 & Lentil-Vegetable-Vegetable & 10 & 0.01 & 1 & Melandaha \\
\hline 38 & Mungbean-Aus- T. Aman & 10 & 0.01 & 1 & Gafargaon \\
\hline 39 & Pea-Vegetable-Fallow & 10 & 0.01 & 1 & Gouripur \\
\hline \multirow[t]{2}{*}{40} & Onion-Aus-Fallow & 5 & 0.00 & 1 & Durgapur \\
\hline & Total area & 1845 & 0.19 & & \\
\hline
\end{tabular}


Table 8. Distribution of the most dominant Boro-Fallow-T. Aman cropping patterns in Mymensingh region, 2014-15.

\begin{tabular}{|c|c|c|c|c|}
\hline & Upazila & Area (ha) & $\%$ of upazila NCA & $\%$ of the pattern in region \\
\hline 01 & Jamalpur sadar & 25200 & 65.81 & 5.34 \\
\hline 02 & Phulpur & 20000 & 82.85 & 4.24 \\
\hline 03 & Purbadhala & 20000 & 85.88 & 4.24 \\
\hline 04 & Nalitabari & 19500 & 81.47 & 4.14 \\
\hline 05 & Nandail & 18900 & 79.45 & 4.01 \\
\hline 06 & Netrokona sadar & 17800 & 77.90 & 3.77 \\
\hline 07 & Gouripur & 17500 & 77.28 & 3.71 \\
\hline 08 & Kendua & 17100 & 72.52 & 3.63 \\
\hline 09 & Muktagachha & 16500 & 72.20 & 3.5 \\
\hline 10 & Bhaluka & 16400 & 72.55 & 3.48 \\
\hline 11 & Ishwarganj & 16400 & 69.91 & 3.48 \\
\hline 12 & Trisal & 16200 & 62.67 & 3.44 \\
\hline 13 & Mymensingh sadar & 16100 & 62.07 & 3.41 \\
\hline 14 & Sherpur sadar & 16000 & 56.94 & 3.39 \\
\hline 15 & Phulbaria & 14000 & 52.24 & 2.97 \\
\hline 16 & Gafargaon & 14000 & 48.43 & 2.97 \\
\hline 17 & Sreebardi & 13100 & 71.11 & 2.78 \\
\hline 18 & Barhatta & 13000 & 82.15 & 2.76 \\
\hline 19 & Haluaghat & 12500 & 46.31 & 2.65 \\
\hline 20 & Melandaha & 11500 & 53.69 & 2.44 \\
\hline 21 & Jhenaigati & 11400 & 74.34 & 2.42 \\
\hline 22 & Dhubaura & 10150 & 64.65 & 2.15 \\
\hline 23 & Islampur & 10000 & 38.76 & 2.12 \\
\hline 24 & Sarishabari & 9200 & 42.74 & 1.95 \\
\hline 25 & Nakla & 9000 & 60.89 & 1.91 \\
\hline 26 & Katiadi & 8500 & 53.56 & 1.8 \\
\hline 27 & Atpara & 8000 & 57.85 & 1.7 \\
\hline 28 & Durgapur & 7200 & 39.11 & 1.53 \\
\hline 29 & Madarganj & 7100 & 35.78 & 1.51 \\
\hline 30 & Dewanganj & 6200 & 33.79 & 1.31 \\
\hline 31 & Baksiganj & 6100 & 39.13 & 1.29 \\
\hline 32 & Madan & 6100 & 33.32 & 1.29 \\
\hline 33 & Karimganj & 5700 & 39.56 & 1.21 \\
\hline 34 & Bajitpur & 5600 & 38.05 & 1.19 \\
\hline 35 & Mohanganj & 5500 & 34.2 & 1.17 \\
\hline 36 & Pakundia & 5400 & 44.55 & 1.15 \\
\hline 37 & Kuliarchar & 4550 & 48.84 & 0.96 \\
\hline 38 & Kishoreganj sadar & 3800 & 28.32 & 0.81 \\
\hline 39 & Kalmakanda & 3500 & 12.30 & 0.74 \\
\hline 40 & Tarail & 3100 & 23.70 & 0.66 \\
\hline 41 & Hossainpur & 1800 & 19.91 & 0.38 \\
\hline 42 & Bhairab & 1100 & 15.58 & 0.23 \\
\hline 43 & Astogram & 400 & 1.55 & 0.08 \\
\hline 44 & Itna & 250 & 0.81 & 0.05 \\
\hline 45 & Nikli & 100 & 0.58 & 0.02 \\
\hline \multirow[t]{2}{*}{46} & Khaliajuri & 100 & 0.52 & 0.02 \\
\hline & Mymensingh region & 471550 & 49.60 & 100.00 \\
\hline
\end{tabular}


Table 9. Distribution of the $2^{\text {nd }}$ dominant Boro-F-F cropping patterns in Mymensingh region, $2014-15$.

\begin{tabular}{|c|c|c|c|c|}
\hline & Upazila & Area (ha) & $\%$ of upazila NCA & $\%$ of the pattern in region \\
\hline 01 & Itna & 27500 & 89.00 & 12.58 \\
\hline 02 & Astogram & 23200 & 89.91 & 10.61 \\
\hline 03 & Khaliajuri & 18200 & 95.24 & 8.32 \\
\hline 04 & Kalmakanda & 16400 & 57.66 & 7.50 \\
\hline 05 & Mithamoin & 16000 & 94.67 & 7.32 \\
\hline 06 & Nikli & 14500 & 84.28 & 6.63 \\
\hline 07 & Durgapur & 10200 & 55.40 & 4.66 \\
\hline 08 & Madan & 9200 & 50.25 & 4.21 \\
\hline 09 & Mohanganj & 8700 & 54.10 & 3.98 \\
\hline 10 & Haluaghat & 8200 & 30.38 & 3.75 \\
\hline 11 & Tarail & 6200 & 47.40 & 2.84 \\
\hline 12 & Gafargaon & 5800 & 20.06 & 2.65 \\
\hline 13 & Bajitpur & 5200 & 35.33 & 2.38 \\
\hline 14 & Kendua & 4500 & 19.08 & 2.06 \\
\hline 15 & Atpara & 4000 & 28.92 & 1.83 \\
\hline 16 & Ishwarganj & 3600 & 15.35 & 1.65 \\
\hline 17 & Netrokona sadar & 3600 & 15.75 & 1.65 \\
\hline 18 & Phulbaria & 3500 & 13.06 & 1.60 \\
\hline 19 & Gouripur & 2800 & 12.36 & 1.28 \\
\hline 20 & Karimganj & 2700 & 18.74 & 1.23 \\
\hline 21 & Purbadhala & 2000 & 8.59 & 0.91 \\
\hline 22 & Dhubaura & 1900 & 12.10 & 0.87 \\
\hline 23 & Madarganj & 1850 & 9.32 & 0.85 \\
\hline 24 & Bhairab & 1800 & 25.50 & 0.82 \\
\hline 25 & Katiadi & 1800 & 11.34 & 0.82 \\
\hline 26 & Sarishabari & 1500 & 6.97 & 0.69 \\
\hline 27 & Kuliarchar & 1500 & 16.10 & 0.69 \\
\hline 28 & Sherpur sadar & 1500 & 5.34 & 0.69 \\
\hline 29 & Barhatta & 1400 & 8.85 & 0.64 \\
\hline 30 & Nandail & 1300 & 5.46 & 0.59 \\
\hline 31 & Muktagachha & 1200 & 5.25 & 0.55 \\
\hline 32 & Bhaluka & 1100 & 4.87 & 0.50 \\
\hline 33 & Melandaha & 830 & 3.87 & 0.38 \\
\hline 34 & Kishoreganj sadar & 800 & 5.96 & 0.37 \\
\hline 35 & Baksiganj & 750 & 4.81 & 0.34 \\
\hline 36 & Sreebardi & 750 & 4.07 & 0.34 \\
\hline 37 & Hossainpur & 500 & 5.53 & 0.23 \\
\hline 38 & Jhenaigati & 500 & 3.26 & 0.23 \\
\hline 39 & Phulpur & 400 & 1.66 & 0.18 \\
\hline 40 & Pakundia & 300 & 2.47 & 0.14 \\
\hline 41 & Mymensingh sadar & 260 & 1.00 & 0.12 \\
\hline 42 & Trisal & 260 & 1.01 & 0.12 \\
\hline 43 & Nalitabari & 200 & 0.84 & 0.09 \\
\hline 44 & Islampur & 150 & 0.58 & 0.07 \\
\hline \multirow[t]{2}{*}{45} & Jamalpur sadar & 100 & 0.26 & 0.05 \\
\hline & Mymensingh region & 218650 & 23.00 & 100.00 \\
\hline
\end{tabular}


Table 10. Distribution of the $3^{\text {rd }}$ dominant Mustard-Boro-T. Aman cropping patterns in Mymensingh region, 2014-15.

\begin{tabular}{|c|c|c|c|c|}
\hline & Upazila & Area (ha) & $\%$ of upazila NCA & $\%$ of the pattern in region \\
\hline 01 & Jamalpur sadar & 3300 & 8.62 & 14.82 \\
\hline 02 & Sarishabari & 2800 & 13.01 & 12.57 \\
\hline 03 & Sherpur sadar & 1900 & 6.76 & 8.53 \\
\hline 04 & Madarganj & 1800 & 9.07 & 8.08 \\
\hline 05 & Melandaha & 1600 & 7.47 & 7.18 \\
\hline 06 & Nalitabari & 1600 & 6.68 & 7.18 \\
\hline 07 & Dewanganj & 1400 & 7.63 & 6.29 \\
\hline 08 & Karimganj & 1200 & 8.33 & 5.39 \\
\hline 09 & Nakla & 1000 & 6.77 & 4.49 \\
\hline 10 & Phulpur & 700 & 2.90 & 3.14 \\
\hline 11 & Mymensingh sadar & 700 & 2.70 & 3.14 \\
\hline 12 & Sreebardi & 700 & 3.80 & 3.14 \\
\hline 13 & Baksiganj & 600 & 3.85 & 2.69 \\
\hline 14 & Trisal & 600 & 2.32 & 2.69 \\
\hline 15 & Muktagachha & 400 & 1.75 & 1.80 \\
\hline 16 & Netrokona sadar & 300 & 1.31 & 1.35 \\
\hline 17 & Gouripur & 250 & 1.10 & 1.12 \\
\hline 18 & Madan & 250 & 1.37 & 1.12 \\
\hline 19 & Jhenaigati & 250 & 1.63 & 1.12 \\
\hline 20 & Barhatta & 200 & 1.26 & 0.90 \\
\hline 21 & Kuliarchar & 150 & 1.61 & 0.67 \\
\hline 22 & Phulbaria & 150 & 0.56 & 0.67 \\
\hline 23 & Pakundia & 100 & 0.82 & 0.45 \\
\hline 24 & Purbadhala & 100 & 0.43 & 0.45 \\
\hline 25 & Dhubaura & 80 & 0.51 & 0.36 \\
\hline 26 & Atpara & 50 & 0.36 & 0.22 \\
\hline 27 & Nandail & 40 & 0.17 & 0.18 \\
\hline 28 & Durgapur & 40 & 0.22 & 0.18 \\
\hline \multirow[t]{2}{*}{29} & Bhaluka & 10 & 0.04 & 0.04 \\
\hline & Mymensingh region & 22270 & 2.34 & 100.00 \\
\hline
\end{tabular}

upazilas and representing $2.29 \%$ share of NCA in Mymensingh region (Table11). The major share of this pattern was from Hossainpur, Kishoreganj sadar, Phulbaria, Pakundia and Katiadi upazilas. Hossainpur upazila of Kishoreganj district ranked in top position occupying 4,200 ha area which is $46.45 \%$ of upazila NCA. The least area coverage was reported in Nakla, Trisal, Mymensingh sadar, Dhubaura, Bhaluka, Kuliarchar and Madarganj upazilas for this pattern. Though continuous rice cropping was not suggested by the researchers and extension personnel, however, this type of land is not suitable for cultivation of non-rice crops.

\section{Fifth dominant cropping pattern}

Boro-Jute-T. Aman cropping pattern holds the fifth largest area coverage 18,150 ha distributed in 15 out of 47 upazilas in Mymensingh region (Table 12). However, their magnitude of contribution to the region was different, ranging 0.55 (Nakla) to $2.69 \%$ (Madarganj) of the NCA. In consideration of indivdual upazila, Madarganj upazila has allocated the highest area and it was $21.67 \%$ of its NCA for this pattern alone. Nakla, kuliarchar, Hossainpur and Bajitpur upazila had negligible area coverage for this pattern.

\section{Crop diversity and cropping intensity}

Higher number of available crops under cultivation in an area dictates its higher diversity. Number of cropping patterns was also a gross indicator of crop diversity. A total of 129 cropping patterns were identified in the whole area of Mymensingh region under this 
Table 11. Distribution of the $4^{\text {th }}$ dominant Boro-Aus-T. Aman cropping patterns in Mymensingh region, 2014-15.

\begin{tabular}{|c|c|c|c|c|}
\hline & Upazila & Area (ha) & $\%$ of upazila NCA & $\%$ of the pattern in region \\
\hline 01 & Hossainpur & 4200 & 46.45 & 19.31 \\
\hline 02 & Kishoreganj sadar & 3800 & 28.32 & 17.47 \\
\hline 03 & Phulbaria & 3300 & 12.31 & 15.17 \\
\hline 04 & Pakundia & 2100 & 17.32 & 9.66 \\
\hline 05 & Katiadi & 1700 & 10.71 & 7.82 \\
\hline 06 & Gafargaon & 1300 & 4.50 & 5.98 \\
\hline 07 & Nandail & 1200 & 5.04 & 5.52 \\
\hline 08 & Haluaghat & 1000 & 3.71 & 4.60 \\
\hline 09 & Sreebardi & 700 & 3.80 & 3.22 \\
\hline 10 & Muktagachha & 600 & 2.63 & 2.76 \\
\hline 11 & Ishwarganj & 400 & 1.71 & 1.84 \\
\hline 12 & Nalitabari & 400 & 1.67 & 1.84 \\
\hline 13 & Karimganj & 300 & 2.08 & 1.38 \\
\hline 14 & Bajitpur & 200 & 1.36 & 0.92 \\
\hline 15 & Jhenaigati & 200 & 1.30 & 0.92 \\
\hline 16 & Madarganj & 50 & 0.25 & 0.23 \\
\hline 17 & Kuliarchar & 50 & 0.54 & 0.23 \\
\hline 18 & Bhaluka & 50 & 0.22 & 0.23 \\
\hline 19 & Dhubaura & 50 & 0.32 & 0.23 \\
\hline 20 & Mymensingh & 50 & 0.19 & 0.23 \\
\hline 21 & Trisal & 50 & 0.19 & 0.23 \\
\hline \multirow[t]{2}{*}{22} & Nakla & 50 & 0.34 & 0.23 \\
\hline & Mymensingh region & 21750 & 2.29 & 100.00 \\
\hline
\end{tabular}

Table 12. Distribution of the $5^{\text {th }}$ dominant Boro-Jute-T. Aman cropping patterns in Mymensingh region, 2014-15.

\begin{tabular}{llccc}
\hline & Upazila & Area (ha) & \% of upazila NCA & \% of the pattern in region \\
\hline 01 & Madarganj & 4300 & 21.67 & 23.69 \\
02 & Melandaha & 3000 & 14.01 & 16.53 \\
03 & Baksiganj & 2300 & 14.75 & 12.67 \\
04 & Sarishabari & 2300 & 10.68 & 12.67 \\
05 & Islampur & 1300 & 5.04 & 7.16 \\
06 & Dewanganj & 1200 & 6.54 & 6.61 \\
07 & Mymensingh sadar & 1000 & 3.86 & 5.51 \\
08 & Trisal & 950 & 3.68 & 5.23 \\
09 & Sherpur sadar & 600 & 2.14 & 3.31 \\
10 & Sreebardi & 550 & 2.99 & 3.03 \\
11 & Bhaluka & 200 & 0.88 & 1.10 \\
12 & Bajitpur & 150 & 1.02 & 0.83 \\
13 & Hossainpur & 100 & 1.11 & 0.55 \\
14 & Kuliarchar & 100 & 1.07 & 0.55 \\
15 & Nakla & 100 & 0.68 & 0.55 \\
\hline & Mymensingh region & 18150 & 1.91 & 100.00 \\
\hline
\end{tabular}


Table 13. Crop diversity and cropping intensity in Mymensingh region, 2014-15.

\begin{tabular}{|c|c|c|c|c|c|c|}
\hline & Upazila & $\begin{array}{l}\text { No. of identified } \\
\text { pattern }\end{array}$ & No. of crop & $\begin{array}{l}\text { Diversity index for } \\
\text { cropping pattern }\end{array}$ & $\begin{array}{l}\text { Crop diversity } \\
\text { index (CDI) }\end{array}$ & C.I. $(\%)$ \\
\hline 1 & Baksiganj & 29 & 17 & 0.806 & 0.923 & 235 \\
\hline 2 & Dewanganj & 17 & 13 & 0.847 & 0.933 & 222 \\
\hline 3 & Islampur & 21 & 16 & 0.817 & 0.913 & 208 \\
\hline 4 & Jamalpur sadar & 25 & 19 & 0.554 & 0.795 & 211 \\
\hline 5 & Madarganj & 22 & 18 & 0.789 & 0.915 & 242 \\
\hline 6 & Melandaha & 21 & 14 & 0.680 & 0.863 & 222 \\
\hline 7 & Sarishabari & 25 & 18 & 0.779 & 0.899 & 216 \\
\hline 8 & Astogram & 22 & 14 & 0.191 & 0.271 & 106 \\
\hline 9 & Bajitpur & 16 & 13 & 0.722 & 0.848 & 170 \\
\hline 10 & Bhairab & 14 & 12 & 0.837 & 0.920 & 189 \\
\hline 11 & Hossainpur & 28 & 14 & 0.733 & 0.876 & 249 \\
\hline 12 & Itna & 14 & 13 & 0.206 & 0.216 & 101 \\
\hline 13 & Karimganj & 22 & 18 & 0.788 & 0.906 & 209 \\
\hline 14 & Kishoreganj sadar & 18 & 17 & 0.814 & 0.911 & 227 \\
\hline 15 & Katiadi & 22 & 19 & 0.686 & 0.849 & 205 \\
\hline 16 & Kuliarchar & 25 & 14 & 0.728 & 0.859 & 194 \\
\hline 17 & Mithamoin & 14 & 13 & 0.103 & 0.111 & 101 \\
\hline 18 & Nikli & 15 & 13 & 0.287 & 0.391 & 109 \\
\hline 19 & Pakundia & 30 & 17 & 0.763 & 0.902 & 231 \\
\hline 20 & Tarail & 17 & 15 & 0.693 & 0.809 & 140 \\
\hline 21 & Bhaluka & 17 & 14 & 0.463 & 0.693 & 188 \\
\hline 22 & Dhubaura & 20 & 13 & 0.555 & 0.745 & 187 \\
\hline 23 & Phulbaria & 21 & 16 & 0.692 & 0.840 & 197 \\
\hline 24 & Phulpur & 29 & 17 & 0.311 & 0.679 & 209 \\
\hline 25 & Gafargaon & 25 & 18 & 0.698 & 0.844 & 192 \\
\hline 26 & Gouripur & 19 & 14 & 0.386 & 0.662 & 191 \\
\hline 27 & Haluaghat & 16 & 12 & 0.682 & 0.825 & 178 \\
\hline 28 & Iswarganj & 12 & 8 & 0.486 & 0.733 & 195 \\
\hline 29 & Muktagachha & 14 & 12 & 0.471 & 0.725 & 197 \\
\hline 30 & Mymensingh sadar & 25 & 21 & 0.594 & 0.835 & 226 \\
\hline 31 & Nandail & 14 & 12 & 0.362 & 0.691 & 204 \\
\hline 32 & Trisal & 19 & 15 & 0.587 & 0.830 & 224 \\
\hline 33 & Atpara & 13 & 11 & 0.577 & 0.741 & 173 \\
\hline 34 & Barhatta & 11 & 9 & 0.316 & 0.644 & 197 \\
\hline 35 & Durgapur & 19 & 14 & 0.540 & 0.707 & 146 \\
\hline 36 & Kalmakanda & 14 & 11 & 0.620 & 0.731 & 122 \\
\hline 37 & Kendua & 15 & 14 & 0.437 & 0.682 & 186 \\
\hline 38 & Khaliajuri & 16 & 15 & 0.093 & 0.114 & 102 \\
\hline 39 & Madan & 12 & 10 & 0.633 & 0.781 & 150 \\
\hline 40 & Mohanganj & 27 & 15 & 0.588 & 0.744 & 146 \\
\hline 41 & Netrokona sadar & 11 & 10 & 0.368 & 0.645 & 188 \\
\hline 42 & Purbadhala & 13 & 11 & 0.255 & 0.604 & 195 \\
\hline 43 & Jhenaigati & 18 & 13 & 0.440 & 0.704 & 196 \\
\hline 44 & Nakla & 20 & 12 & 0.611 & 0.831 & 218 \\
\hline 45 & Nalitabari & 15 & 10 & 0.330 & 0.684 & 207 \\
\hline 46 & Sherpur sadar & 15 & 10 & 0.654 & 0.859 & 225 \\
\hline \multirow[t]{2}{*}{47} & Sreebardi & 10 & 8 & 0.485 & 0.762 & 210 \\
\hline & Mymensingh region & 129 & 37 & 0.699 & 0.840 & 187 \\
\hline
\end{tabular}


investigation. The highest number of cropping patterns was identified 30 in Pakundia upazila and that was 29 in Baksiganj and Phulpur; 28 in Hossainpur and 27 in Mohanganj (Table 13). The lowest number of cropping patterns was identified 10 in Sreebardi followed by 11 in Barhatta and Netrokona sadar both. The higher number of cropping patterns is generally related to higher level crop diversity indices. The upazilas having lower number of cropping patterns were related to either water logging or discontinuous region occurring as a narrow strip of land at the foot of the northern and eastern hills or both. The lowest diversity index for cropping pattern was recorded 0.103 in Mithamoin followed by 0.191 in Astogram and 0.206 in Itna. The highest value of diversity index for cropping pattern was found 0.847 in Dewanganj upazila that was followed by 0.837 in Bhairab upazila. The calculated diversity indices (CDI) for cropping pattern are presented in Table 13. The lowest CDI was reported 0.111 in Mithamoin followed by 0.114 in Khaliajuri. The highest value of CDI was observed 0.933 in Dewanganj followed by 0.920 in Bhairab upazila. The range of cropping intensity values was recorded $101-249 \%$. The maximum value was for Hossainpur upazila and minimum for Itna and Mithamoin upazilas of Kishoreganj district. As a whole the CDI of Mymensingh region was calculated 0.840 and the average cropping intensity at regional level was $187 \%$. In a simultaneous study, the investigators identified 316 cropping patterns for whole Bangladesh; where the CDI value was 0.952 at national level and the national average of cropping intensity was 200\% (Nasim et al., 2017). Diversification of crops helps risk reduction as diversification allows a producer to balance low price in one or two crops with reasonable prices in other. (Blade and Slinkard, 2002). In India the farmers of Kerala diversified their cropping pattern to minimize crop failures and price fluctuations (Mahesh, 1999).

\section{CONCLUSION}

The cropping intensity of the Mymensingh region was little bit lower than the national average. Boro-Fallow-T. Aman, Single
Boro, Mustard-Boro-T. Aman, Boro-Aus- T. Aman, Boro-Jute-T. Aman were the dominant cropping patterns in the region. These scenarios throw a challenge to biodiversity, food and nutritional security for the people of the region. Based on the findings of the study, the following recommendations were made.

- Initiative to be taken to increase productivity of exclusive rice based cropping pattern along with recommended crop management packages.

- Some of the portion of double-rice area could be brought under Mustard-Boro-T. Aman and / or Boro-Jute-T. Aman cropping systems.

- In the single Boro area suitable vegetable might be grown on floating bed system in wet season.

- The upazilas having unique or exceptional cropping patterns with large area coverage might be studied in-depth to extrapolate to similar environments.

\section{REFERENCES}

Alam, S and Abedin, M J. 1996. Changing cropping pattern in Bangladesh from 1971-75 through 199193: Implicationson crop sector growth. Bangladesh J. Agric. Econs. XIX: 31-44.

Agrawal, D J and A H Kassam. 1976. The importance of multiple cropping in increasing world food supplies. A special publication No. 27, American Society of Agronomy, Madison, Wisconsin. pp. 2-3.

BBS (Bangladesh Bureau of Statistics). 2014. Statistical Yearbook of Bangladesh. Statistics Division, Ministry of Planning, Government of the People's Republic of Bangladesh.

Blade, S F and A E Slinkard. 2002. New Crop Development: The Canadian Experience. In: Trends in New Crops and New Uses. J Janick and A Whipkey (Editors). ASHS Press, Alexandria.

Das, Anup, G I Ramkrushna, GS Yadav, J Layek, C Debnath, B U Choudhury, K P Mohaptara, S V Ngachan and $S$ Das. 2015. Capturing traditional practices of rice based farming systems and identifying interventions for resource conservation and food security in Tripura, India. Applied Ecology and Environmental Sciences. 3(4): 100-107.

Cropping Patterns in Mymensingh 
FAO, 1988. Land Resources Appraisal of Bangladesh for Agricultural Development- Report 2: Agroecological regions of Bangladesh. Food and Agriculture Organization of the United Nations, Rome, Italy, 570p.

Gadge, S S. 2003. Influence of changes in cropping pattern on farmers' economic status. Indian J. Ext. Edu. 39(1\&2): 99-101.

Hossain, D. 1996. Relative profitability from alternative cropping patterns under irrigated conditions in selected areas of Bogra district. M. S. Ag. Econ.Thesis. Bangladesh Agricultural University, Mymensingh.

Hussain, A M M, M Hossain and A Janaiah. 2001. Hybrid rice adoption in Bangladesh: Socio-economic assessment of farmers' experiences. BRAC Research Monograph Series.No. 18.BRAC, Dhaka, Bangladesh.

Kshirsagar, K G, S Pandey and M R Bellon. 1997. Farmers' perception, varietal characteristics and technology adoption: The case of rainfed village in eastern India. Discussion paper 5/97. Social Science Division, IRRI.

Kumari, B A P, S Thiruchelvam, H M H Dissanayake and $\mathrm{T}$ Lasantha. 2010. Crop diversification and income inequality in irrigation systems: The case of Minipe. Tropical Agricultural Research. 21: 308-320.

Mahesh, R. 1999. Causes and consequences of change in cropping pattern: A location specific study. Discussion Paper No. 11, Kerala Research Programme on Local
Level Development, Centre for Development Studies, Thiruvananthapura.

Mandal, R and M P Bezbaruah. 2013. Diversification of cropping pattern: its determinants and role in flood affected agriculture of Assam Plains. Indian J Agric. Econ. 68(2): 169-181.

Mondal, R I, F Begum, A Aziz and S H Sharif. 2015. Crop sequences for increasing cropping intensity and productivity.SAARC J. Agri. 13: 135-147.

Nasim, M, S M Shahidullah, A Saha, M A Muttaleb, T L Aditya, M A Ali and M S Kabir. 2017. Distribution of Crops and Cropping Patterns in Bangladesh. Bangladesh Rice J. 21(2): 1-55.

Neena, D. 1998. Interstate variation in cropping pattern in India. Indian J. Regi. Sci. 30(2): 57-69.

Rahman, A. 2010.Promotingfinancial inclusion for poverty reduction with inclusive growth. Bazlur Rahman Memorial Lecture, presented at the 17th biennial conference on 'The economy at the golden jubilee of war of liberation: what type of Bangladesh we would like to see?' organized by Bangladesh Economic Association held on 8-10 April at Osmani Memorial Auditorium and Institution of Engineers, Bangladesh Dhaka.

Shahidullah, S M, M S A Talukder, M S Kabir, A H Khan and N E Elahi. 2006. Cropping patterns in the South East Coastal Region of Bangladesh. J. Agric. Rural Dev. 4(1\&2): 53-60. 
Appendix 1. List of cropping patterns in Mymensingh region, 2014-15.

\begin{tabular}{|c|c|c|c|c|c|}
\hline & Cropping pattern & Area (ha) & & Cropping pattern & Area (ha) \\
\hline 01 & Boro-Fallow- T. Aman & 471550 & 46 & Maize-Aus-Fallow & 1000 \\
\hline 02 & Boro-Fallow-Fallow & 218650 & 47 & Potato-Fallow- T. Aman & 1000 \\
\hline 03 & Mustard-Boro- T. Aman & 22270 & 48 & Wheat-Aus-Fallow & 1000 \\
\hline 04 & Boro-Aus- T. Aman & 21750 & 49 & Fallow-Vegetable- T. Aman & 980 \\
\hline 05 & Boro-Jute- T. Aman & 18150 & 50 & Onion-Jute- T. Aman & 940 \\
\hline 06 & Fallow-Aus- T. Aman & 12110 & 51 & Boro-Vegetable(Float/Norm) & 900 \\
\hline 07 & Mustard-Boro-Fallow & 12090 & 52 & Vegetable-Aus-Fallow & 900 \\
\hline 08 & Fallow-Fallow- T. Aman & 11180 & 53 & Onion-Vegtab-Vegetable & 885 \\
\hline 09 & Vegetable-Vegetable- T. Aman & 8910 & 54 & Potato-Jute-Fallow & 810 \\
\hline 10 & Vegetable-Vegetable-Vegetable & 8500 & 55 & Onion-Fallow- T. Aman & 805 \\
\hline 11 & Vegetable-Fallow- T. Aman & 7460 & 56 & Lentil-Jute- T. Aman & 745 \\
\hline 12 & Wheat-Jute- T. Aman & 7150 & 57 & Wheat-Aus- T. Aman & 740 \\
\hline 13 & Potato-Boro- T. Aman & 6080 & 58 & Vegetable-Boro-Fallow & 690 \\
\hline 14 & Fallow-Jute- T. Aman & 5540 & 59 & Blackgram-Aus- T. Aman & 680 \\
\hline 15 & Vegetable-Boro- T. Aman & 4730 & 60 & Blackgram-Jute- T. Aman & 670 \\
\hline 16 & Vegetable-Vegetable-Fallow & 4550 & 61 & Grasspea-Jute-Fallow & 660 \\
\hline 17 & Potato-Jute- T. Aman & 4360 & 62 & Garlic-Vegetable-Vegetable & 640 \\
\hline 18 & Maize-Jute-Fallow & 3890 & 63 & Garlic-Fallow- T. Aman & 610 \\
\hline 19 & Vegetable-Fallow-Fallow & 3630 & 64 & Mustard-Aus- T. Aman & 580 \\
\hline 20 & Chilli-Boro-Jute & 3600 & 65 & Mustard-Fallow-Fallow & 540 \\
\hline 21 & Vegetable-Jute- T. Aman & 3520 & 66 & Chilli-Vegetable- T. Aman & 515 \\
\hline 22 & Boro-Vegetable- T. Aman & 3420 & 67 & Blackgram-Jute-Fallow & 500 \\
\hline 23 & Chilli-Aus-Fallow & 2935 & 68 & Boro-Aus-Fallow & 500 \\
\hline 24 & Wheat-Jute-Fallow & 2820 & 69 & Vegetable-Boro-Jute & 500 \\
\hline 25 & Sweet potato-Fallow-Fallow & 2700 & 70 & Garlic-Jute-Fallow & 480 \\
\hline 26 & Chilli-Jute-Fallow & 2670 & 71 & Lentil-Jute-Fallow & 470 \\
\hline 27 & Fallow-Fallow-Blackgram & 2400 & 72 & Wheat-Vegetable-Vegetable & 460 \\
\hline 28 & Boro-Jute-Fallow & 2330 & 73 & Mustard-Boro-Aus- T. Aman & 420 \\
\hline 29 & Maize-Jute- T. Aman & 2220 & 74 & Potato-Aus-Fallow & 400 \\
\hline 30 & Vegetable-Jute-Fallow & 2170 & 75 & Maize-Fallow- T. Aman & 355 \\
\hline 31 & Wheat-Fallow- T. Aman & 2030 & 76 & Mustard-Fallow- T. Aman & 350 \\
\hline 32 & Chilli-Fallow-Fallow & 2000 & 77 & Garlic-Jute- T. Aman & 340 \\
\hline 33 & Groundnut-Fallow-Fallow & 1875 & 78 & Potato-Boro-Jute & 340 \\
\hline 34 & Boro-Fallow-Blackgram & 1870 & 79 & Groundnut-Jute- T. Aman & 330 \\
\hline 35 & Chilli-Fallow- T. Aman & 1840 & 80 & Potato-Chilli-Fallow & 330 \\
\hline 36 & Mustard-Jute- T. Aman & 1840 & 81 & Sweet potato-Fallow- T.Aman & 310 \\
\hline 37 & Potato-Boro-Fallow & 1770 & 82 & Lentil-Aus- T. Aman & 305 \\
\hline 38 & Onion-Jute-Fallow & 1720 & 83 & Sweet potato-Jute-Fallow & 300 \\
\hline 39 & Vegetable-Aus- T. Aman & 1350 & 84 & Chilli-Aus- T. Aman & 250 \\
\hline 40 & Chilli-Vegetable-Fallow & 1225 & 85 & Wheat-Jute-Blackgram & 250 \\
\hline 41 & Mustard-Jute-Fallow & 1210 & 86 & Coriander-Fallow-Fallow & 205 \\
\hline 42 & Potato-Aus- T. Aman & 1210 & 87 & Vegetable-Fallow-Blackgram & 180 \\
\hline 43 & Maize-Fallow-Fallow & 1160 & 88 & Coriander-Fallow- T. Aman & 170 \\
\hline 44 & Chilli-Jute- T. Aman & 1150 & 89 & Coriander-Jute-Fallow & 170 \\
\hline 45 & Potato-Vegetable- T. Aman & 1090 & $90-129$ & Other 40 patterns (Table 7) & 1845 \\
\hline
\end{tabular}


